\title{
Performance of Low-input Turfgrass Species as Affected by Mowing and Nitrogen Fertilization in Minnesota
}

\author{
Kari L. Hugie \\ USDA-ARS Coastal Plains Soil, Water, and Plant Research Center, 2611 \\ West Lucas Street, Florence, SC 29501
}

Eric Watkins ${ }^{1}$

Department of Horticultural Science, University of Minnesota, 1970 Folwell Avenue, St. Paul, MN 55108

Additional index words. hard fescue, prairie junegrass, tufted hairgrass, colonial bentgrass, nitrogen fertilizer, mowing

\begin{abstract}
In Minnesota, most lawns and higher cut turfgrass areas consist primarily of species such as kentucky bluegrass (Poa pratensis L.) and perennial ryegrass (Lolium perenne $\mathrm{L}$.) that require significant management inputs such as frequent mowing and nitrogen fertility. Several studies have shown that other species have the potential to be used more widely on home lawns in Minnesota; however, little is known about the management requirements of these species. In this study, we evaluated the performance of several alternative grass species under varying mowing and nitrogen fertility regimes at two sites in Minnesota in 2010 and 2011. Hard fescue [Festuca trachyphylla (Hackel) Krajina] showed the most consistent performance across management regimes, seasons, and locations. Colonial bentgrass (Agrostis tenuis Sibth.) showed good spring and fall turf quality, but suffered from excess thatch development and disease incidence. 'Barkoel' prairie junegrass [Koeleria macrantha (Ledeb.) Schult] maintained acceptable turf cover throughout the trial, whereas unimproved native prairie junegrass populations did poorly regardless of management level. Tufted hairgrass [Deschampsia cespitosa (L.) P. Beauv.] did not perform consistently in the trial due to summer stress. Our results show that hard fescue, colonial bentgrass, and 'Barkoel' prairie junegrass performed well regardless of mowing height or fertility treatment and could be used to a greater degree as low-input turfgrasses in Minnesota.
\end{abstract}

Turfgrass species traditionally used in residential and commercial lawns in Minnesota, such as kentucky bluegrass $(P$. pratensis $)$ and perennial ryegrass (L. perenne), can require significant management inputs to maintain acceptable cover and quality. For instance, perennial ryegrass generally has better quality at lower mowing heights $(3.8 \mathrm{~cm}$ compared with 5.0 or $6.3 \mathrm{~cm}$ ); this increased level of maintenance also results in higher weed pressure than when the grass is maintained at higher heights of cut (Miltner et al., 2005). Kentucky bluegrass typically requires high input levels for maintaining adequate quality (DeBels et al., 2012), and may not perform as well as other species when inputs are limited (Watkins et al., 2014). Turfgrass breeders have worked to improve these species for use in lower-input situations (Bonos and Huff, 2013), but the use of alternative species is another promising approach.

Received for publication 6 June 2016. Accepted for publication 5 Aug. 2016.

This material is based on research supported by the Cooperative State Research, Education, and Extension Service, U.S. Department of Agriculture, under agreement no. 2009-34381-20044.

${ }^{1}$ Corresponding author. E-mail: ewatkins@umn. edu.
A number of researchers have investigated other species for their adaptation in the north central region (NCR) of the United States and regions with similar climates. Diesburg et al. (1997) evaluated a single cultivar representing each of several grass species at multiple sites in the NCR under low-input management $(20 \mathrm{~kg} \mathrm{~N} / \mathrm{ha} /$ year after establishment at most locations with limited use of a broadleaf herbicide) and found that most grasses performed best at $7.6 \mathrm{~cm}$. The top performing grasses at that mowing height were 'Alta' tall fescue (Festuca arundinacea Schreb.), 'Exeter' colonial bentgrass (A. tenuis Sibth.), 'Reton' redtop (Agrostis alba L. Reton), and 'Covar' common sheep fescue (Festuca ovina L.). In a separate multistate trial in the NCR, Watkins et al. (2011) found that under lowinput management (no fertilization after establishment, no pesticides, no irrigation) at both 5.1- and 10.2-cm mowing heights, the top performing species were colonial bentgrass, tall fescue, hard fescue $[F$. trachyphylla (Hackel) Krajina], and sheep fescue. Tall fescue, chewings fescue (Festuca rubra spp. fallax Thuill), hard fescue, and colonial bentgrass performed best overall in a follow-up study evaluating greater number of cultivars at $5.1 \mathrm{~cm}$ (Watkins et al., 2014).
It is becoming clear that there are a number of lawn grass species that can serve as alternatives to kentucky bluegrass and perennial ryegrass. Yet, for many of these alternative species, information on their performance under various management regimes is lacking. Of the species that have the greatest potential for use in the NCR under low-input management, tall fescue is the best studied, and its mowing height and fertility requirements are well established.

The species both lacking management information and representing the most potential as low-input turfgrasses in Minnesota are hard fescue and colonial bentgrass. Prairie junegrass and tufted hairgrass have also shown potential in field trials in Minnesota (Watkins and Clark, 2009; Watkins et al., 2009). These species have shown varying levels of quality when grown as turfgrass, and there are great differences in the amount of plant breeding effort that has been focused on them. Hard fescue, while underused, has been the focus of some breeding efforts since the middle of the 20th century (Bonos and Huff, 2013), whereas tufted hairgrass and prairie junegrass lacked focused breeding efforts by public breeding programs until recent decades (Watkins et al., 2013). European types of prairie junegrass have been used for a longer period by private breeders in Europe (Alderson and Sharp, 1994), although these have not been able to achieve significant market penetration in the United States.

For the most part, the mowing and fertilization requirements of these species are not well known. Hard fescue has been the focus of the most research of the four; however, the body of literature is much less developed than for other highly used cool-season turfgrass species such as perennial ryegrass and kentucky bluegrass. The objective of this study was to determine the performance of the four low-input cool-season turfgrass species under various mowing heights and nitrogen fertility regimes when grown in Minnesota.

\section{Materials and Methods}

Turfgrass plots were seeded in late summer of 2009 at two locations: the Turfgrass Research, Outreach, and Education Center in St. Paul, MN (seeded 18 August), and the University of Minnesota Landscape Arboretum in Chaska, MN (seeded 3 September). The trial at St. Paul was planted on a Waukegan silt loam (pH 7.5, 38 ppm P, 292 ppm K, $3.4 \%$ organic matter); whereas the trial at Chaska was planted on a poor-quality urban soil ( $\mathrm{pH} 7.9,6$ ppm P, 153 ppm K, 1.7\% organic matter) that consisted of a mixture of construction material sourced from an excavation site nearby and Lester Kilkenny loam. Before seeding at Chaska, the site was amended with compost derived from leaf litter and yard waste to a depth of $7.6 \mathrm{~cm}$. Seventeen turfgrass entries were chosen for the study (Table 1) including four entries each of hard fescue, colonial bentgrass, and prairie junegrass, and three entries of tufted 
hairgrass. The four entries of prairie junegrass consisted of one cultivar of European origin and three unimproved experimental populations originating from germplasm collections made in Colorado (CO pop.), North Dakota (ND pop.), or Minnesota of kentucky bluegrass and perennial ryegrass from the University of Minnesota breeding program were planted to represent the two species typically used in lawns in Minnesota.

The experiment was a split-split plot design with four replications. Mowing height was the main plot, nitrogen rate was the sub plot, and cultivar/selection was the sub-sub plot (individual plot size $1.0 \times 1.5 \mathrm{~m}$ ). A starter fertilizer $(24.5 \mathrm{~kg} \mathrm{~N} / \mathrm{ha} ; 21.6 \mathrm{~kg} \mathrm{P} / \mathrm{ha}$; (MN pop.). In addition, one cultivar each

$23.7 \mathrm{~kg} \mathrm{~K} / \mathrm{ha}$ ) was applied at seeding, and the plots were irrigated during establishment. After establishment in the fall of 2009, plots received no irrigation or pesticide applications for the duration of the study. Mowing occurred once or twice each week, with clippings returned, during the growing season at one of the three mowing heights: 3.2 , 5.7 , or $8.3 \mathrm{~cm}$. Fertilizer treatments during both 2010 and 2011 were applied using Renaissance $^{\circledR}$ All Natural Organic fertilizer (9N-0.0P-7.4K) (PJC \& Company Ecological Land Care, Inc., Rowley, MA) at one of the three rates: 1) no fertilizer; 2) $49 \mathrm{~kg} \mathrm{~N} / \mathrm{ha} /$ year applied in early September; and 3) 98 $\mathrm{kg} \mathrm{N} / \mathrm{ha} /$ year (applied as a split application with $49 \mathrm{~kg} \mathrm{~N} / \mathrm{ha}$ applied in late May and $49 \mathrm{~kg} \mathrm{~N} / \mathrm{ha}$ applied in early September).

Table 1. List of turfgrass cultivars and selections, along with seeding rates, for plots established at St. Paul (Aug. 18) and Chaska, MN (Sept. 3), in 2009.

\begin{tabular}{lcl}
\hline Species & Seeding rate $\left(\mathrm{g} \cdot \mathrm{m}^{-2}\right)$ & \multicolumn{1}{c}{ Cultivar or selection } \\
\hline Colonial bentgrass & 5.3 & Alister, BarKing, Glory, SR 7150 \\
Hard fescue & 16.7 & Spartan II, Reliant IV, MNHD, ${ }^{\mathrm{z}}$ SR 3150 \\
Prairie junegrass & 13.3 & MN pop., ${ }^{\mathrm{z}}$ ND pop., ${ }^{\mathrm{z}}$ CO pop., ${ }^{\mathrm{z}}$ Barkoel \\
Tufted hairgrass & 13.3 & DCS, ${ }^{\mathrm{z}}$ DCM, Barcampsia \\
Perennial ryegrass & 16.7 & Arctic Green \\
Kentucky bluegrass & 10.0 & MSP $3769^{\mathrm{z}}$ \\
\hline
\end{tabular}

$\mathrm{CO}$ pop. $=$ population originating from germplasm collections made in Colorado; $\mathrm{MN}$ pop. $=$ population originating from germplasm collections made in Minnesota; ND pop. = population originating from germplasm collections made in North Dakota.

${ }^{2}$ From the University of Minnesota turfgrass breeding program.

Table 2. Split-split plot analysis of variance of TQ, percent (\%) live turfgrass cover, and percent (\%) weed cover for cultivars and selections at St. Paul, MN, in 2010 and 2011.

\begin{tabular}{|c|c|c|c|c|c|c|}
\hline Source & df & Spring & $\frac{\mathrm{TQ}^{\mathrm{z}}}{\text { Summer }}$ & Fall & $\begin{array}{l}\text { Percent live } \\
\text { cover }^{y}\end{array}$ & $\begin{array}{l}\text { Percent weed } \\
\text { cover }^{y}\end{array}$ \\
\hline \multicolumn{7}{|l|}{2010} \\
\hline Mowing height (MH) & 2 & NS & * & * & ** & * \\
\hline Fertilizer treatment $(\mathrm{F})$ & 2 & ** & * & $* * *$ & NS & NS \\
\hline $\mathrm{MH} \times \mathrm{F}$ & 4 & NS & NS & NS & NS & NS \\
\hline Cultivar/selection (C) & 16 & $* * *$ & $* * *$ & $* * *$ & $* * *$ & $* * *$ \\
\hline HF vs. PR & 1 & $* * *$ & $* * *$ & $* * *$ & * & $*$ \\
\hline HF vs. KB & 1 & $* * *$ & $* * *$ & $* * *$ & NS & NS \\
\hline $\mathrm{CO}$ vs. $\mathrm{PR}$ & 1 & $* * *$ & *** & * & NS & NS \\
\hline $\mathrm{CO}$ vs. $\mathrm{KB}$ & 1 & $* * *$ & $* * *$ & $* * *$ & NS & NS \\
\hline TH vs. PR & 1 & $* * *$ & $*$ & $* * *$ & NS & NS \\
\hline TH vs. KB & 1 & $* * *$ & $* * *$ & $* * *$ & NS & NS \\
\hline $\mathrm{C} \times \mathrm{MH}$ & 32 & $* * *$ & $* * *$ & $* * *$ & NS & NS \\
\hline $\mathrm{C} \times \mathrm{F}$ & 32 & NS & NS & NS & NS & NS \\
\hline $\mathrm{C} \times \mathrm{MH} \times \mathrm{F}$ & 64 & NS & NS & NS & NS & NS \\
\hline \multicolumn{7}{|l|}{2011} \\
\hline MH & 2 & NS & NS & ** & NS & NS \\
\hline Fertilizer treatment $(\mathrm{F})$ & 2 & $* * *$ & $* * *$ & $* * *$ & NS & NS \\
\hline $\mathrm{MH} \times \mathrm{F}$ & 4 & NS & NS & NS & NS & NS \\
\hline Cultivar/selection (C) & 16 & $* * *$ & $* * *$ & $* * *$ & $* * *$ & $* * *$ \\
\hline HF vs. PR & 1 & $* * *$ & $* * *$ & $* * *$ & NS & NS \\
\hline HF vs. KB & 1 & $* * *$ & $* * *$ & $* * *$ & $* * *$ & $* * *$ \\
\hline $\mathrm{CO}$ vs. $\mathrm{PR}$ & 1 & $* * *$ & $* * *$ & $*$ & NS & $* * *$ \\
\hline $\mathrm{CO}$ vs. KB & 1 & $*$ & $* * *$ & $*$ & $* * *$ & $* * *$ \\
\hline TH vs. PR & 1 & NS & $* * *$ & $* * *$ & $* *$ & NS \\
\hline TH vs. KB & 1 & $*$ & $* * *$ & $* * *$ & $* *$ & $* * *$ \\
\hline $\mathrm{C} \times \mathrm{MH}$ & 32 & $* * *$ & NS & $* * *$ & NS & NS \\
\hline $\mathrm{C} \times \mathrm{F}$ & 32 & NS & ** & NS & NS & NS \\
\hline $\mathrm{C} \times \mathrm{MH} \times \mathrm{F}$ & 64 & NS & NS & NS & NS & NS \\
\hline
\end{tabular}

$\mathrm{CO}=$ colonial bentgrass; $\mathrm{HF}=$ hard fescue $\mathrm{KB}=$ kentucky bluegrass; $\mathrm{PR}=$ perennial ryegrass; $\mathrm{TH}=$ tufted hairgrass; TQ = turfgrass quality.

${ }^{2} \mathrm{TQ}$ was rated on a $1-9$ scale $(1=$ dead/fully dormant turf, $9=$ ideal turf $)$ twice a month from May through October. May and June ratings were averaged for spring TQ; July and August ratings were averaged for summer TQ; and September and October ratings were averaged for fall TQ.

${ }^{\text {y }}$ Percent live turfgrass cover and weed cover were calculated using the grid intersect method. Measurements were taken in the fall of 2010 and 2011.

$*, * *, * * *$ Significant at $\alpha=0.05,0.01$, and 0.001 , respectively. NS $=$ nonsignificant.
Mean daily temperature from 1 Apr. to 13 Oct. during 2010 and 2011 was similar at both St. Paul $\left(16.9\right.$ and $16.2^{\circ} \mathrm{C}$ in 2010 and 2011, respectively) and Chaska (16.4 and $15.8{ }^{\circ} \mathrm{C}$ in 2010 and 2011 , respectively). Precipitation for the same period at St. Paul was $752 \mathrm{~mm}$ in 2010 and $745 \mathrm{~mm}$ in 2011, whereas at Chaska it was 748 and $527 \mathrm{~mm}$ in 2010 and 2011, respectively (cli-MATE, 2015).

Visual ratings of turfgrass quality were taken using a $1-9$ scale $(1=$ poor, $5=$ minimally acceptable, $9=$ excellent) twice each month from May through October in both 2010 and 2011. Turfgrass quality ratings were primarily based on uniformity, density, texture, and freedom from weeds and diseases. Quantitative data were collected on percent live turfgrass cover and percent weed cover in Fall of 2010 and 2011 using the grid intersect method by placing a $0.3 \times 0.9 \mathrm{~m}$ grid with 33 intersects twice at random on each plot. The number of grid intersections with live turfgrass or weed cover was counted and converted into a percentage of the total area to obtain percent live turfgrass cover and weed cover for each plot.

Turfgrass quality data were initially subjected to repeated measures analysis of variance (ANOVA) using the MIXED procedure in the Statistical Analysis Software (SAS) package (data not shown) (Version 9.4; SAS Institute Inc., Cary, NC). Due to significant $(\alpha=0.05)$ cultivar/selection $\times$ location and cultivar/selection $\times$ year interactions, locations and years were analyzed separately. Monthly turfgrass quality ratings were averaged by season in 2010 and 2011. Specifically, May and June ratings were averaged to create a single quality rating for spring, July and August ratings were averaged for summer, and September and October ratings were averaged for fall. Data were then analyzed using the GLM procedure in SAS to conduct a split-split plot ANOVA treating replication, mowing height, fertilizer treatment, and cultivar/selection as fixed effects. Single df contrasts were constructed to compare species performance across mowing height and fertility treatments. All means comparisons were conducted using Fisher's protected least significant difference using the LSMEANS statement in SAS. When a significant cultivar/ selection $\times$ treatment effect was detected, the SLICE statement was used to test the significance of treatment effects within cultivars/ selections.

\section{Results}

Turfgrass quality. At St. Paul, mowing height affected turfgrass quality in Summer and Fall 2010 and 2011, whereas fertility treatment and cultivar/selection effects on turfgrass quality were significant for all seasons (Table 2). There was a significant mowing height $\times$ cultivar/selection interaction in all seasons except Summer 2011, and there was a significant nitrogen fertility treatment $\times$ cultivar/selection interaction in Summer 2011. The mowing height $\times$ fertility 
Table 3. Seasonal $\mathrm{TQ}^{\mathrm{z}}$ by mowing height, fertilizer treatment, and cultivar/selection at St. Paul, MN, in 2010 and 2011.

\begin{tabular}{|c|c|c|c|c|c|c|}
\hline & \multicolumn{3}{|c|}{ TQ, 2010} & \multicolumn{3}{|c|}{ TQ, 2011} \\
\hline & Spring & Summer & $\overline{\text { Fall }}$ & Spring & Summer & Fall \\
\hline \multicolumn{7}{|l|}{ Mowing height (cm) } \\
\hline 3.2 & $4.9 \mathrm{a}$ & $4.3 \mathrm{a}$ & $4.2 \mathrm{a}$ & $5.0 \mathrm{a}$ & $4.6 \mathrm{a}$ & $4.4 \mathrm{a}$ \\
\hline 5.7 & $4.9 \mathrm{a}$ & $3.8 \mathrm{ab}$ & $3.2 \mathrm{~b}$ & $4.6 \mathrm{a}$ & $4.5 \mathrm{a}$ & $3.9 \mathrm{~b}$ \\
\hline 8.3 & $4.9 \mathrm{a}$ & $3.5 \mathrm{~b}$ & $3.0 \mathrm{~b}$ & $4.6 \mathrm{a}$ & $4.4 \mathrm{a}$ & $3.8 \mathrm{~b}$ \\
\hline \multicolumn{7}{|c|}{ Fertilizer treatment $(\mathrm{kg} \mathrm{N} / \mathrm{ha})$} \\
\hline 0 & $4.8 \mathrm{~b}$ & $3.8 \mathrm{~b}$ & $3.3 \mathrm{c}$ & $4.4 \mathrm{~b}$ & $4.3 \mathrm{~b}$ & $3.8 \mathrm{c}$ \\
\hline 49 & $4.9 \mathrm{a}$ & $3.8 \mathrm{~b}$ & $3.5 \mathrm{~b}$ & $4.8 \mathrm{a}$ & $4.5 \mathrm{~b}$ & $4.0 \mathrm{~b}$ \\
\hline 98 & $5.0 \mathrm{a}$ & $4.1 \mathrm{a}$ & $3.7 \mathrm{a}$ & $4.9 \mathrm{a}$ & $4.8 \mathrm{a}$ & $4.2 \mathrm{a}$ \\
\hline \multicolumn{7}{|c|}{ Cultivar/selection (species) } \\
\hline Arctic Green (PR) & $4.7 \mathrm{e}^{\mathrm{y}}$ & $3.3 \mathrm{~g}$ & $3.7 \mathrm{~d}$ & $5.3 \mathrm{~cd}$ & $4.5 \mathrm{f}$ & $4.5 \mathrm{~cd}$ \\
\hline MSP $3769(\mathrm{~KB})$ & $4.4 \mathrm{e}$ & $4.9 \mathrm{~b}$ & $4.1 \mathrm{c}$ & $4.7 \mathrm{ef}$ & $4.4 \mathrm{f}$ & $4.0 \mathrm{f}$ \\
\hline MNHD (HF) & $5.9 \mathrm{~cd}$ & $6.3 \mathrm{a}$ & $6.0 \mathrm{a}$ & $6.5 \mathrm{a}$ & $7.0 \mathrm{a}$ & $6.7 \mathrm{a}$ \\
\hline SR 3150 (HF) & $3.1 \mathrm{f}$ & $4.0 \mathrm{~cd}$ & $5.2 \mathrm{~b}$ & $6.2 \mathrm{ab}$ & $6.6 \mathrm{bc}$ & $6.4 \mathrm{ab}$ \\
\hline Spartan II (HF) & $6.0 \mathrm{bc}$ & $6.0 \mathrm{a}$ & $5.8 \mathrm{a}$ & $6.1 \mathrm{~b}$ & $6.5 \mathrm{c}$ & $6.1 \mathrm{~b}$ \\
\hline Reliant IV (HF) & $6.2 \mathrm{~b}$ & $6.1 \mathrm{a}$ & $6.1 \mathrm{a}$ & $6.4 \mathrm{ab}$ & $6.8 \mathrm{ab}$ & $6.5 \mathrm{a}$ \\
\hline BarKing $(\mathrm{CO})$ & $6.3 \mathrm{ab}$ & $4.1 \mathrm{~cd}$ & $3.5 \mathrm{~d}$ & $4.0 \mathrm{~g}$ & $4.9 \mathrm{e}$ & $4.2 \mathrm{ef}$ \\
\hline Glory $(\mathrm{CO})$ & $6.2 \mathrm{bc}$ & $4.3 \mathrm{c}$ & $3.6 \mathrm{~d}$ & $4.6 \mathrm{ef}$ & $5.2 \mathrm{~d}$ & $4.4 \mathrm{de}$ \\
\hline Alister (CO) & $6.2 \mathrm{~b}$ & $4.2 \mathrm{~cd}$ & $3.6 \mathrm{~d}$ & $4.5 \mathrm{f}$ & $5.3 \mathrm{~d}$ & $4.4 \mathrm{de}$ \\
\hline SR $7150(\mathrm{CO})$ & $6.1 \mathrm{bc}$ & $3.9 \mathrm{de}$ & $3.0 \mathrm{e}$ & $4.6 \mathrm{f}$ & $5.2 \mathrm{de}$ & $4.1 \mathrm{f}$ \\
\hline Barkoel (PJ) & $4.5 \mathrm{e}$ & $4.2 \mathrm{~cd}$ & $3.6 \mathrm{~d}$ & $5.6 \mathrm{c}$ & $5.2 \mathrm{~d}$ & $4.8 \mathrm{c}$ \\
\hline MN pop. (PJ) & $1.7 \mathrm{~g}$ & $1.3 \mathrm{~h}$ & $1.0 \mathrm{~h}$ & $2.0 \mathrm{i}$ & $1.4 \mathrm{~h}$ & $1.1 \mathrm{~h}$ \\
\hline $\mathrm{CO}$ pop. (PJ) & $1.9 \mathrm{~g}$ & $1.3 \mathrm{~h}$ & $1.0 \mathrm{~h}$ & $1.8 \mathrm{i}$ & $1.4 \mathrm{~h}$ & $1.1 \mathrm{~h}$ \\
\hline ND pop. (PJ) & $2.0 \mathrm{~g}$ & $1.3 \mathrm{~h}$ & $1.0 \mathrm{~h}$ & $2.4 \mathrm{~h}$ & $1.6 \mathrm{~h}$ & $1.2 \mathrm{~h}$ \\
\hline Barcampsia (TH) & $6.6 \mathrm{a}$ & $3.6 \mathrm{e}-\mathrm{g}$ & $2.6 \mathrm{fg}$ & $5.0 \mathrm{de}$ & $3.5 \mathrm{~g}$ & $3.0 \mathrm{~g}$ \\
\hline $\mathrm{DCM}(\mathrm{TH})$ & $5.6 \mathrm{~d}$ & 3.7 ef & $2.7 \mathrm{ef}$ & $4.8 \mathrm{ef}$ & $3.5 \mathrm{~g}$ & $3.1 \mathrm{~g}$ \\
\hline DCS $(\mathrm{TH})$ & $6.2 \mathrm{~b}$ & $3.5 \mathrm{fg}$ & $2.2 \mathrm{~g}$ & $5.3 \mathrm{~cd}$ & $3.4 \mathrm{~g}$ & $2.8 \mathrm{~g}$ \\
\hline
\end{tabular}

$\mathrm{CO}=$ colonial bentgrass; $\mathrm{CO}$ pop. $=$ population originating from germplasm collections made in Colorado $\mathrm{HF}=$ hard fescue; $\mathrm{KB}=$ kentucky bluegrass; $\mathrm{MN}$ pop. = population originating from germplasm collections made in Minnesota; ND pop. = population originating from germplasm collections made in North Dakota; $\mathrm{PJ}=$ prairie junegrass; $\mathrm{PR}=$ perennial ryegrass; $\mathrm{TH}=$ tufted hairgrass; $\mathrm{TQ}=$ turfgrass quality.

${ }^{\mathrm{z}}$ TQ was rated on a $1-9$ scale $(1=$ dead/fully dormant turf, $9=$ ideal turf $)$ twice a month from May through October. May and June ratings were averaged for spring TQ; July and August ratings were averaged for summer TQ; and September and October ratings were averaged for fall TQ.

${ }^{\mathrm{y}}$ Means within the same column and treatment with the same letter are not significantly different $(\alpha=0.05)$ according to Fisher's protected least significant difference (LSD).

Table 4. Significance of mowing height on turfgrass quality within each cultivars or selection at SP and $\mathrm{CH}, \mathrm{MN}$, in 2010 and 2011.

\begin{tabular}{|c|c|c|c|c|c|c|c|c|c|c|c|c|c|}
\hline \multirow{3}{*}{$\begin{array}{l}\text { Cultivar/selection } \\
\text { (species) }\end{array}$} & \multirow[b]{3}{*}{ df } & \multicolumn{6}{|c|}{2010} & \multicolumn{6}{|c|}{2011} \\
\hline & & \multicolumn{2}{|c|}{ Spring } & \multicolumn{2}{|c|}{ Summer } & \multicolumn{2}{|c|}{ Fall } & \multicolumn{2}{|c|}{ Spring } & \multicolumn{2}{|c|}{ Summer } & \multicolumn{2}{|c|}{ Fall } \\
\hline & & SP & $\overline{\mathrm{CH}}$ & SP & $\overline{\mathrm{CH}}$ & $\overline{\mathrm{SP}}$ & $\overline{\mathrm{CH}}$ & SP & $\overline{\mathrm{CH}}$ & SP & $\mathrm{CH}$ & SP & $\mathrm{CH}$ \\
\hline Arctic Green (PR) & 2 & $* *$ & $* * *$ & $* * *$ & $* * *$ & $* * *$ & $* * *$ & NS & $* *$ & NS & $* * *$ & $* * *$ & $* *$ \\
\hline MSP $3769(\mathrm{~KB})$ & 2 & $*$ & NS & NS & $* * *$ & $* * *$ & $* * *$ & NS & $* * *$ & NS & $* * *$ & $* *$ & $* *$ \\
\hline MNHD (HF) & 2 & $* *$ & $* * *$ & $* * *$ & $* * *$ & $* * *$ & $* * *$ & NS & $* * *$ & NS & $* * *$ & NS & $* * *$ \\
\hline SR 3150 (HF) & 2 & NS & $* * *$ & $* * *$ & $* * *$ & $* * *$ & $* * *$ & NS & $* *$ & NS & $* * *$ & NS & $* * *$ \\
\hline Spartan II (HF) & 2 & NS & $* * *$ & $* * *$ & $* * *$ & $* * *$ & $* * *$ & NS & $*$ & NS & NS & NS & $* * *$ \\
\hline Reliant IV (HF) & 2 & $* *$ & $* * *$ & $* * *$ & $* * *$ & $* * *$ & $* * *$ & NS & $* * *$ & NS & $* * *$ & NS & $* * *$ \\
\hline BarKing (CO) & 2 & $* * *$ & NS & NS & $* * *$ & $* * *$ & $* * *$ & $* * *$ & $* * *$ & NS & NS & $* * *$ & NS \\
\hline Glory (CO) & 2 & NS & $* * *$ & NS & $* * *$ & $* * *$ & $* * *$ & $* * *$ & $*$ & NS & NS & $* * *$ & NS \\
\hline Alister (CO) & 2 & NS & NS & NS & $* * *$ & $* * *$ & $* * *$ & $* * *$ & $* *$ & NS & $*$ & $* * *$ & NS \\
\hline SR $7150(\mathrm{CO})$ & 2 & $* * *$ & NS & NS & NS & $* * *$ & NS & $* * *$ & $*$ & NS & NS & $* *$ & NS \\
\hline Barkoel (PJ) & 2 & $* * *$ & $* *$ & $* * *$ & $* * *$ & $* * *$ & $* * *$ & $* *$ & $* * *$ & NS & $* * *$ & $* * *$ & NS \\
\hline $\mathrm{MN}$ pop. (PJ) & 2 & NS & NS & NS & NS & NS & NS & NS & NS & NS & NS & NS & NS \\
\hline $\mathrm{CO}$ pop. (PJ) & 2 & NS & NS & NS & NS & NS & NS & NS & NS & NS & NS & NS & NS \\
\hline ND pop. (PJ) & 2 & NS & NS & NS & NS & $* * *$ & NS & NS & NS & NS & NS & NS & NS \\
\hline Barcampsia (TH) & 2 & NS & $*$ & $* *$ & $* * *$ & $* * *$ & $* * *$ & NS & $* *$ & NS & $* *$ & NS & NS \\
\hline $\mathrm{DCM}(\mathrm{TH})$ & 2 & $* * *$ & $* * *$ & NS & $* * *$ & $* * *$ & $* *$ & NS & $*$ & NS & $*$ & NS & NS \\
\hline $\operatorname{DCS}(\mathrm{TH})$ & 2 & NS & NS & $* * *$ & $* * *$ & $* * *$ & NS & NS & $* *$ & NS & $*$ & $* *$ & NS \\
\hline
\end{tabular}

$\mathrm{CH}=$ Chaska; $\mathrm{CO}=$ colonial bentgrass; $\mathrm{CO}$ pop. $=$ population originating from germplasm collections made in Colorado; $\mathrm{HF}=$ hard fescue; $\mathrm{KB}=$ kentucky bluegrass; $\mathrm{MN}$ pop. = population originating from germplasm collections made in Minnesota; ND pop. = population originating from germplasm collections made in North Dakota; PJ $=$ prairie junegrass; $\mathrm{PR}=$ perennial ryegrass; $\mathrm{SP}=\mathrm{St}$. $\mathrm{Paul}$; $\mathrm{TH}=$ tufted hairgrass.

$*, * *, * *$ Significant at $\alpha=0.05,0.01$, and 0.001 , respectively. $\mathrm{NS}=$ nonsignificant.

interaction, however, was not significant in any season during the study. Although the interaction between mowing height $\times$ cultivar/ selection was highly significant at St. Paul, the average mean squares of the two-way interaction in 2010 and 2011 (2.27 and 0.90 , respectively) were substantially smaller than the average mean squares for the main effect of cultivar/selection (95.38 in 2010 and 104.62 in 2011) and mowing height (39.73 in 2010 and 11.06 in 2011). Thus, means comparisons of turfgrass quality based on the main effects of cultivar/selection, mowing height, and fertility treatment are presented in Table 3. The lowest mowing height $(3.2 \mathrm{~cm})$ and highest nitrogen fertility treatment $(98$ $\mathrm{kg} \mathrm{N} /$ ha/year) generally resulted in the highest turfgrass quality across cultivars/selections.

Contrasts indicated that there were differences in turfgrass quality between the lowinput species (i.e., hard fescue, colonial bentgrass, and tufted hairgrass) and 'Arctic Green' perennial ryegrass and 'MSP 3769' kentucky bluegrass across all seasons and years at St. Paul, with only one exception; in Spring 2011, there was no significant difference in turfgrass quality between the tufted hairgrass entries and 'Arctic Green' (Table 2). The prairie junegrass entries were not grouped and included in the species contrasts due to the extreme differences in quality and performance between 'Barkoel' and the native populations. The hard fescue entries had the highest average turfgrass quality across mowing heights and nitrogen fertility treatments, whereas the native prairie junegrass populations had the lowest turfgrass quality (Table 3).

Means were sliced to test for the significance of mowing height within each cultivar/ selection (Table 4). In Spring 2010 at St. Paul, mowing height had inconsistent effects on turfgrass quality depending on the cultivar/ selection (Fig. 1). Arctic Green perennial ryegrass, 'BarKing' and 'SR 7150' colonial bentgrass, and 'DCM' tufted hairgrass had better turfgrass quality at higher mowing heights; whereas MSP 3769 kentucky bluegrass, 'MNHD' and 'Reliant IV' hard fescue, and Barkoel prairie junegrass had higher turfgrass quality at the lower mowing heights. The turfgrass quality of the remaining cultivars/selections was unaffected by mowing height. For the remainder of the study at St. Paul (Summer 2010 through Fall 2011), the 3.2-cm mowing height resulted in the highest turfgrass quality for cultivars/ selections affected by mowing height (data not shown). Means were also sliced to test the significance of fertility treatment within each cultivar/selection in Summer 2011 (data not shown). Turfgrass quality in Summer 2011 for the colonial bentgrass cultivars, prairie junegrass entries, DCM and 'DCS' tufted hairgrass was unaffected by fertility treatment. For all other cultivars/selections, turfgrass quality improved with increasing nitrogen fertility.

At Chaska, the main effects of mowing height, fertility treatment, and cultivar/ selection were significant in all seasons of both 2010 and 2011 (Table 5). Turfgrass quality was affected by a fertility treatment $x$ cultivar/selection interaction in several seasons, and all seasons showed a significant mowing height $\times$ cultivar/selection interaction. Nevertheless, in 2010 and 2011 the average mean squares of the fertility treatment $\times$ cultivar/selection interaction $(0.70$ and 0.53 , 


\section{St. Paul--Spring 2010}

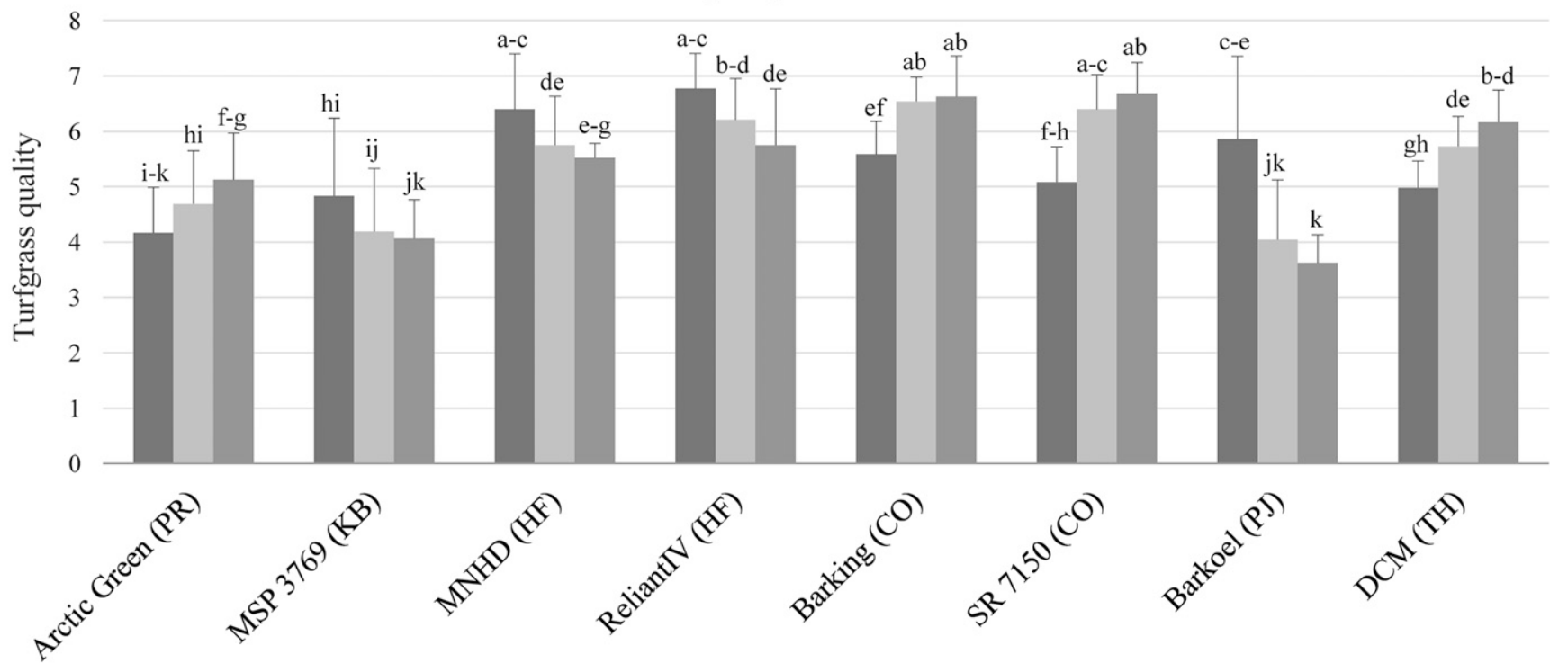

Chaska--Fall 2011

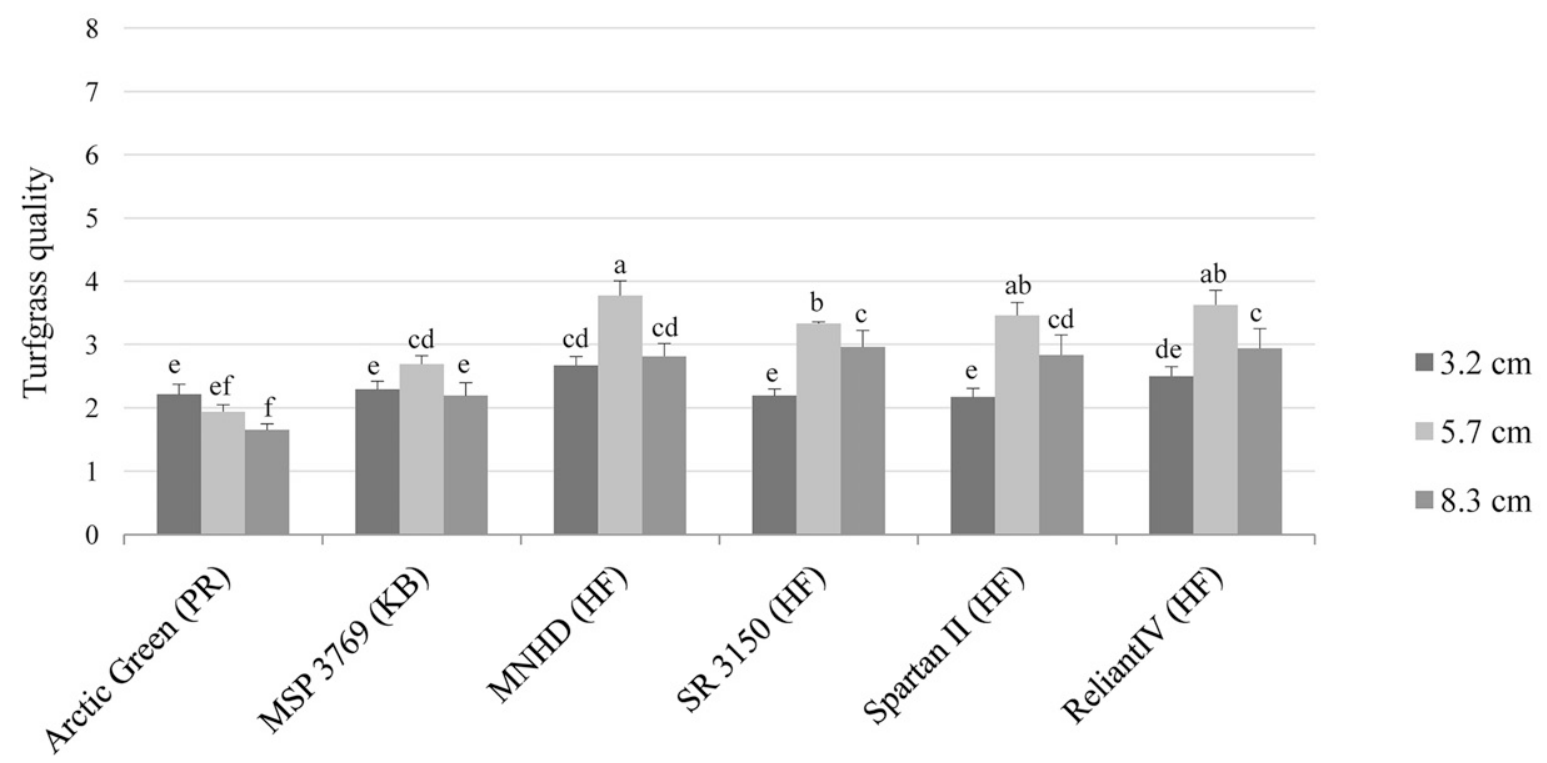

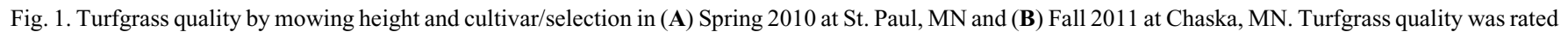
on a 1-9 scale ( $1=$ dead/fully dormant turf, $9=$ ideal turf) twice a month from May through October in 2010 and 2011 . May and June ratings were averaged for spring, and September and October ratings were averaged for fall. $\mathrm{CO}=$ colonial bentgrass; $\mathrm{HF}=\mathrm{hard}$ fescue; $\mathrm{KB}=\mathrm{kentucky} \mathrm{bluegrass} ; \mathrm{PJ}=$ prairie junegrass; $\mathrm{PR}=$ perennial ryegrass; $\mathrm{TH}=$ tufted hairgrass. Means with the same letter are not significantly different $(\alpha=0.05)$ according to Fisher's protected least significant difference. Mowing height did not affect turfgrass quality within several cultivars/selections as indicated by the effect slice; thus, turfgrass quality for these cultivars/selections is not shown.

respectively) and the mowing height $x$ cultivar/selection interaction (2.34 and 0.84 , respectively) were considerably smaller than the average mean squares for the main effect of cultivar/selection (28.08 in 2010 and 31.04 in 2011) at Chaska. Therefore, means comparisons were performed on the main effects of cultivar/selection, mowing height, and fertility treatment (Table 6). Average turfgrass quality at Chaska was lower in comparison with the average turfgrass quality at St. Paul. Turfgrass quality was generally highest for plots mowed at $3.2 \mathrm{~cm}$ and plots receiving $98 \mathrm{~kg} \mathrm{~N} / \mathrm{ha} /$ year, similar to the results at St. Paul. However, the intermediate mowing height, $5.7 \mathrm{~cm}$, resulted in higher turfgrass quality than either the $3.2-$ or $8.3-\mathrm{cm}$ mowing height in Fall 2011 at Chaska. The hard fescue entries, particularly Reliant IV, maintained the highest turfgrass quality at Chaska after Spring 2010.

Means were sliced to test for the significance of fertility treatment within each cultivar/selection (data not shown). The turfgrass quality of the native prairie junegrass populations was unaffected by fertility treatment at Chaska. However for all other cultivars/selections, higher turfgrass quality was observed with increasing nitrogen fertility. Means were also sliced to test for the significance of mowing height within each cultivar/selection (Table 4). As with fertility, the turfgrass quality of the native prairie junegrass populations was unaffected by mowing height. Turfgrass quality of the remaining cultivar/selections was affected in at least one or more seasons at Chaska, and from Spring 2010 through Summer 2011 the $3.2-\mathrm{cm}$ mowing height resulted in the highest turfgrass quality for all cultivars/ selections affected by mowing height (data not shown). In Fall 2011, the turfgrass quality of Arctic Green perennial ryegrass increased as mowing height decreased, whereas the turfgrass quality of MSP 3769 kentucky bluegrass and the four hard fescue entries was greatest at the intermediate mowing height (Fig. 1). 


\section{Chaska--Fall 2010}

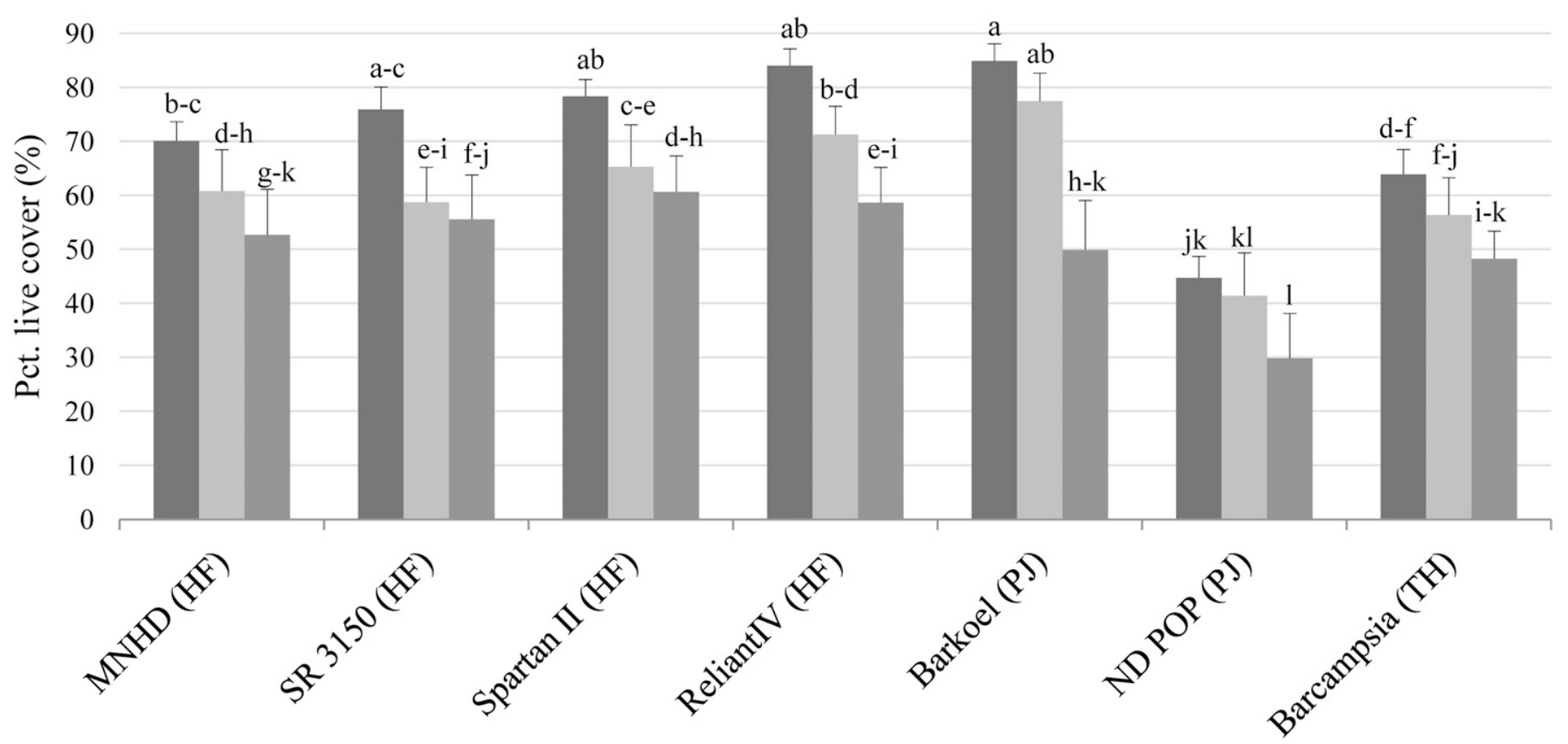

\section{Chaska--Fall 2011}

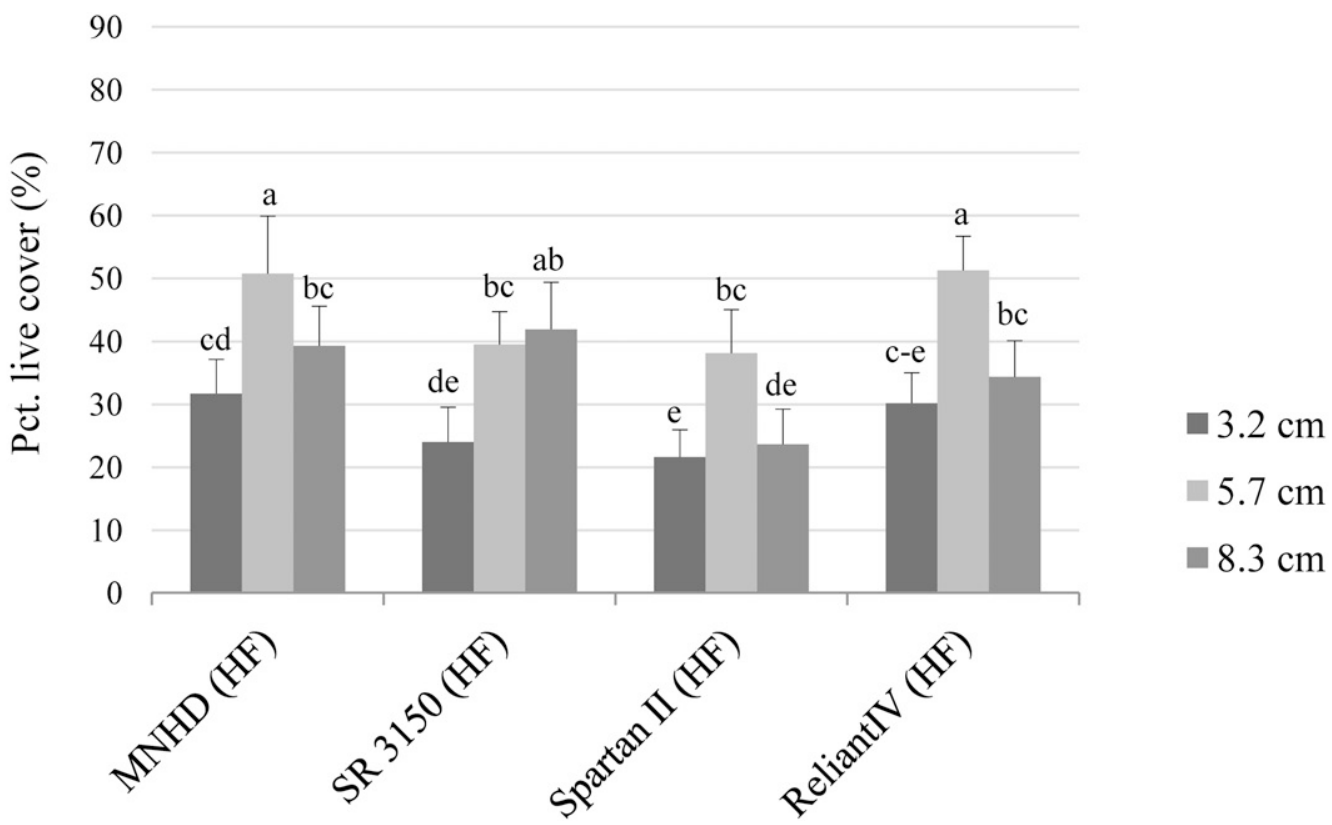

Fig. 2. Percent live turfgrass cover by mowing height and cultivar/selection in Fall (A) 2010 and (B) 2011 at Chaska, MN. Percent live turfgrass cover was calculated using the grid intersect method. $\mathrm{CO}=$ colonial bentgrass; $\mathrm{HF}=$ hard fescue; $\mathrm{KB}=$ kentucky bluegrass; $\mathrm{PJ}=$ prairie junegrass; $\mathrm{PR}=$ perennial ryegrass; TH = tufted hairgrass. Means with the same letter are not significantly different $(\alpha=0.05)$ according to Fisher's protected least significant difference. Mowing height did not affect percent live turfgrass cover within several cultivars/selections as indicated by the effect slice; thus, mean percent live turfgrass cover for these cultivars/selections is not shown.

Living turfgrass cover and weed cover. At St. Paul, mowing height had a significant effect on living turfgrass cover and weed cover in 2010 but not 2011, whereas nitrogen fertility had no effect on living turfgrass cover nor weed cover (Table 2). In 2010, there was greater living turfgrass cover at the low and intermediate mowing heights, likely attributable to greater weed cover at the 8.3-cm mowing height (Table 3). There was little difference in live cover and weed cover between species in 2010, with the exception of prairie junegrass. All cultivars/selections, except for the native prairie junegrass populations, had $>90 \%$ living turfgrass cover in 2010 (Table 7). In 2011, the hard fescue and colonial bentgrass entries, along with Barkoel prairie junegrass, maintained greater percent living turfgrass cover compared with MSP 3769 kentucky bluegrass.
The Chaska site, where the predominant weeds were birdsfoot trefoil (Lotus corniculatus L.) and black medic (Medicago lupulina L.), had much greater weed pressure than St. Paul. Increased weed pressure may have been due to weed seed present in the native urban soil or in the compost that was used on the site (the compost was not evaluated before the study for weed seed). Living turfgrass cover in 2010 and weed cover in 2010 and 
Table 5. Split-split plot analysis of variance of $\mathrm{TQ}^{\mathrm{z}}$, percent (\%) live turfgrass cover, ${ }^{\mathrm{y}}$ and percent $(\%)$ weed cover ${ }^{\mathrm{y}}$ for cultivars and selections at Chaska, MN, in 2010 and 2011.

\begin{tabular}{|c|c|c|c|c|c|c|}
\hline$\underline{\text { Source }}$ & $\mathrm{df}$ & Spring & $\frac{\mathrm{TQ}^{\mathrm{z}}}{\text { Summer }}$ & Fall & $\begin{array}{c}\text { Percent live } \\
\text { cover }^{y}\end{array}$ & $\begin{array}{c}\text { Percent weed } \\
\text { cover }^{\mathrm{y}} \\
\end{array}$ \\
\hline \multicolumn{7}{|l|}{2010} \\
\hline Mowing height (MH) & 2 & $*$ & $*$ & $*$ & NS & $* *$ \\
\hline Fertilizer treatment $(\mathrm{F})$ & 2 & $*$ & $* * *$ & $* * *$ & $* * *$ & $* * *$ \\
\hline $\mathrm{MH} \times \mathrm{F}$ & 4 & NS & NS & NS & NS & NS \\
\hline Cultivar/selection (C) & 16 & $* * *$ & $* * *$ & $* * *$ & $* * *$ & $* * *$ \\
\hline HF vs. PR & 1 & $* * *$ & $* * *$ & $* * *$ & NS & NS \\
\hline HF vs. KB & 1 & $* * *$ & $* * *$ & $* * *$ & $* * *$ & $* * *$ \\
\hline $\mathrm{CO}$ vs. PR & 1 & $* * *$ & $* * *$ & $* * *$ & $* * *$ & $* * *$ \\
\hline $\mathrm{CO}$ vs. $\mathrm{KB}$ & 1 & $* * *$ & NS & NS & $* * *$ & $* * *$ \\
\hline TH vs. PR & 1 & $* * *$ & NS & $* * *$ & $* *$ & NS \\
\hline TH vs. KB & 1 & $* * *$ & $* * *$ & $* * *$ & NS & NS \\
\hline $\mathrm{C} \times \mathrm{MH}$ & 32 & $* * *$ & $* * *$ & $* * *$ & $*$ & NS \\
\hline $\mathrm{C} \times \mathrm{F}$ & 32 & NS & $* * *$ & $* * *$ & NS & NS \\
\hline $\mathrm{C} \times \mathrm{MH} \times \mathrm{F}$ & 64 & NS & NS & NS & NS & NS \\
\hline \multicolumn{7}{|l|}{2011} \\
\hline MH & 2 & * & * & $*$ & NS & $* *$ \\
\hline Fertilizer treatment $(\mathrm{F})$ & 2 & $* * *$ & $* * *$ & $*$ & NS & $* *$ \\
\hline $\mathrm{MH} \times \mathrm{F}$ & 4 & NS & $*$ & NS & NS & NS \\
\hline Cultivar/selection (C) & 16 & $* * *$ & $* * *$ & $* * *$ & $* * *$ & $* * *$ \\
\hline HF vs. PR & 1 & $* * *$ & $* * *$ & $* * *$ & $* * *$ & $*$ \\
\hline HF vs. KB & 1 & $* * *$ & $* * *$ & $* * *$ & $* * *$ & NS \\
\hline CO vs. PR & 1 & $* * *$ & $* *$ & $* * *$ & $* * *$ & $* *$ \\
\hline $\mathrm{CO}$ vs. $\mathrm{KB}$ & 1 & $* * *$ & $* * *$ & $* * *$ & $*$ & $* * *$ \\
\hline TH vs. PR & 1 & NS & $* * *$ & NS & NS & NS \\
\hline TH vs. KB & 1 & $* * *$ & $* * *$ & $* * *$ & NSS & $* * *$ \\
\hline $\mathrm{C} \times \mathrm{MH}$ & 32 & $* * *$ & $* * *$ & $* * *$ & $*$ & NS \\
\hline $\mathrm{C} \times \mathrm{F}$ & 32 & $* * *$ & $* * *$ & NS & NS & NS \\
\hline $\mathrm{C} \times \mathrm{MH} \times \mathrm{F}$ & 64 & NS & NS & NS & NS & NS \\
\hline
\end{tabular}

$\mathrm{CO}=$ colonial bentgrass; $\mathrm{HF}=$ hard fescue; $\mathrm{KB}=$ kentucky bluegrass; $\mathrm{PR}=$ perennial ryegrass; $\mathrm{TH}=$ tufted hairgrass; $\mathrm{TQ}=$ turfgrass quality.

${ }^{\mathrm{z}}$ TQ was rated on a 1-9 scale ( 1 = dead/fully dormant turf, 9 = ideal turf) twice a month from May through October. May and June ratings were averaged for spring TQ; July and August ratings were averaged for summer TQ; and September and October ratings were averaged for fall TQ.

'Percent live turfgrass cover and weed cover were calculated using the grid intersect method. Measurements were taken in the fall of 2010 and 2011 at St. Paul and Chaska, MN.

$*, * *, * *$ Significant at $\alpha=0.05,0.01$, and 0.001 , respectively. NS $=$ nonsignificant.

Table 6. Seasonal TQz by mowing height, fertilizer treatment, and cultivar/selection at Chaska, MN, in 2010 and 2011.

\begin{tabular}{|c|c|c|c|c|c|c|}
\hline & \multicolumn{3}{|c|}{ TQ, 2010} & \multicolumn{3}{|c|}{ TQ, 2011} \\
\hline & Spring & Summer & Fall & Spring & Summer & Fall \\
\hline \multicolumn{7}{|l|}{ Mowing height $(\mathrm{cm})$} \\
\hline 3.2 & $3.8 \mathrm{a}$ & $2.7 \mathrm{a}$ & $3.5 \mathrm{a}$ & $4.1 \mathrm{a}$ & $3.4 \mathrm{a}$ & $1.7 \mathrm{~b}$ \\
\hline 5.7 & $3.3 \mathrm{~b}$ & $1.9 \mathrm{~b}$ & $2.6 \mathrm{~b}$ & $3.9 \mathrm{ab}$ & $3.4 \mathrm{a}$ & $2.0 \mathrm{a}$ \\
\hline 8.3 & $3.1 \mathrm{~b}$ & $1.5 \mathrm{c}$ & $2.0 \mathrm{c}$ & $3.5 \mathrm{~b}$ & $2.9 \mathrm{~b}$ & $1.8 \mathrm{~b}$ \\
\hline \multicolumn{7}{|c|}{ Fertilizer treatment (kg N/ha) } \\
\hline 0 & $3.4 \mathrm{ab}$ & $1.8 \mathrm{~b}$ & $2.3 \mathrm{~b}$ & $3.3 \mathrm{c}$ & $2.9 \mathrm{c}$ & $1.7 \mathrm{~b}$ \\
\hline 49 & $3.3 \mathrm{~b}$ & $1.8 \mathrm{~b}$ & $2.5 \mathrm{~b}$ & $3.8 \mathrm{~b}$ & $3.2 \mathrm{~b}$ & $1.8 \mathrm{a}$ \\
\hline 98 & $3.6 \mathrm{a}$ & $2.5 \mathrm{a}$ & $3.2 \mathrm{a}$ & $4.4 \mathrm{a}$ & $3.5 \mathrm{a}$ & $1.9 \mathrm{a}$ \\
\hline \multicolumn{7}{|c|}{ Cultivar/selection (species) } \\
\hline Arctic Green (PR) & $4.7 \mathrm{a}^{\mathrm{y}}$ & $1.7 \mathrm{~h}$ & $2.6 \mathrm{fg}$ & $3.7 \mathrm{e}$ & $3.5 \mathrm{~d}$ & $1.9 \mathrm{ef}$ \\
\hline MSP $3769(\mathrm{~KB})$ & $2.2 \mathrm{~g}$ & $2.1 \mathrm{ef}$ & $2.9 \mathrm{ef}$ & $3.1 \mathrm{f}$ & $4.0 \mathrm{c}$ & $2.4 \mathrm{~d}$ \\
\hline MNHD (HF) & $3.1 \mathrm{de}$ & $2.8 \mathrm{c}$ & $4.0 \mathrm{bc}$ & $4.8 \mathrm{~b}$ & $4.5 \mathrm{a}$ & $3.1 \mathrm{a}$ \\
\hline SR $3150(\mathrm{HF})$ & $3.0 \mathrm{e}$ & $2.6 \mathrm{~d}$ & $3.8 \mathrm{c}$ & $4.8 \mathrm{~b}$ & $4.4 \mathrm{ab}$ & $2.8 \mathrm{bc}$ \\
\hline Spartan II (HF) & $3.8 \mathrm{c}$ & $3.1 \mathrm{~b}$ & $4.2 \mathrm{ab}$ & $4.8 \mathrm{~b}$ & $4.3 \mathrm{bc}$ & $2.8 \mathrm{c}$ \\
\hline Reliant IV (HF) & $4.0 \mathrm{bc}$ & $3.4 \mathrm{a}$ & $4.4 \mathrm{a}$ & $5.1 \mathrm{a}$ & $4.5 \mathrm{ab}$ & $3.0 \mathrm{ab}$ \\
\hline BarKing (CO) & $4.1 \mathrm{~b}$ & $2.1 \mathrm{e}$ & $2.9 \mathrm{e}$ & $3.8 \mathrm{e}$ & $3.1 \mathrm{e}-\mathrm{g}$ & $1.3 \mathrm{i}$ \\
\hline Glory $(\mathrm{CO})$ & $4.0 \mathrm{~b}$ & $2.2 \mathrm{e}$ & $3.4 \mathrm{~d}$ & $4.6 \mathrm{bc}$ & $3.5 \mathrm{~d}$ & $1.3 \mathrm{hi}$ \\
\hline Alister (CO) & $4.1 \mathrm{~b}$ & $2.2 \mathrm{e}$ & $3.2 \mathrm{~d}$ & $4.3 \mathrm{~cd}$ & $3.3 \mathrm{de}$ & $1.3 \mathrm{hi}$ \\
\hline SR $7150(\mathrm{CO})$ & $3.9 \mathrm{bc}$ & $1.9 \mathrm{fg}$ & $2.5 \mathrm{~g}$ & $4.2 \mathrm{~d}$ & $2.9 \mathrm{~g}$ & $1.2 \mathrm{ij}$ \\
\hline Barkoel (PJ) & $3.3 \mathrm{~d}$ & $2.8 \mathrm{~cd}$ & $3.5 \mathrm{~d}$ & $4.5 \mathrm{~cd}$ & $3.3 \mathrm{de}$ & $1.5 \mathrm{gh}$ \\
\hline $\mathrm{MN}$ pop. (PJ) & $1.9 \mathrm{~h}$ & $1.1 \mathrm{j}$ & $1.1 \mathrm{j}$ & $2.1 \mathrm{~g}$ & $1.3 \mathrm{~h}$ & $1.0 \mathrm{j}$ \\
\hline CO pop. (PJ) & $2.4 \mathrm{fg}$ & $1.1 \mathrm{j}$ & $1.1 \mathrm{j}$ & $2.1 \mathrm{~g}$ & $1.4 \mathrm{~h}$ & $1.0 \mathrm{j}$ \\
\hline ND pop. (PJ) & $2.5 \mathrm{f}$ & $1.1 \mathrm{j}$ & $1.1 \mathrm{ij}$ & $2.3 \mathrm{~g}$ & $1.4 \mathrm{~h}$ & $1.0 \mathrm{j}$ \\
\hline Barcampsia (TH) & $4.0 \mathrm{bc}$ & $1.8 \mathrm{gh}$ & $1.8 \mathrm{~h}$ & $3.8 \mathrm{e}$ & $3.0 \mathrm{fg}$ & $1.6 \mathrm{~g}$ \\
\hline $\operatorname{DCM}(\mathrm{TH})$ & $3.8 \mathrm{c}$ & $1.6 \mathrm{hi}$ & $1.8 \mathrm{~h}$ & $3.9 \mathrm{e}$ & $3.2 \mathrm{ef}$ & $2.1 \mathrm{e}$ \\
\hline DCS $(\mathrm{TH})$ & $3.2 \mathrm{de}$ & $1.4 \mathrm{i}$ & $1.4 \mathrm{i}$ & $3.3 \mathrm{f}$ & 3.1 ef & $1.8 \mathrm{f}$ \\
\hline
\end{tabular}

$\mathrm{CO}=$ colonial bentgrass $; \mathrm{CO}$ pop.$=$ population originating from germplasm collections made in Colorado $\mathrm{HF}=$ hard fescue; $\mathrm{KB}=$ kentucky bluegrass; $\mathrm{MN}$ pop. = population originating from germplasm collections made in Minnesota; ND pop. = population originating from germplasm collections made in North Dakota; $\mathrm{PJ}=$ prairie junegrass; $\mathrm{PR}=$ perennial ryegrass; $\mathrm{TH}=\mathrm{tufted}$ hairgrass; TQ $=$ turfgrass quality.

${ }^{z}$ TQ was rated on a 1-9 scale $(1=$ dead/fully dormant turf, $9=$ ideal turf $)$ twice a month from May through October. May and June ratings were averaged for spring TQ; July and August ratings were averaged for summer TQ; and September and October ratings were averaged for fall TQ.

'Means within the same column and treatment with the same letter are not significantly different $(\alpha=0.05)$ according to Fisher's protected least significant difference.
2011 were affected by mowing height (Table 5). Although the main effect of mowing height was not significant in 2011, there was a significant cultivar/selection $\times$ mowing height interaction in both 2010 and 2011 . Living turfgrass cover in 2010 and weed cover in 2010 and 2011 were also affected by nitrogen fertility, and there were cultivar/ selection differences in living cover and weed cover across both years. The low and intermediate mowing heights and the $98 \mathrm{~kg}$ $\mathrm{N} / \mathrm{ha} /$ year treatment generally reduced weed cover and resulted in greater living turfgrass cover at Chaska (Table 8). The colonial bentgrass entries had the greatest percent living turfgrass cover in 2010 and the least amount of weed cover in both 2010 and 2011, whereas the hard fescue entries outperformed all other cultivars/selections in regard to percent living cover in 2011 at Chaska. It should be noted that all cultivars/selections at the Chaska site showed unacceptably low turf cover at the end of the trial, which may have been due to lower rainfall at that site during the 2011 growing season.

Means were sliced to test for the significance of mowing height within each cultivar/ selection (Table 9). Mowing height affected percent living turfgrass cover for Barkoel prairie junegrass, the native prairie junegrass population from ND, and 'Barcampsia' tufted hairgrass in 2010, and the hard fescue entries in both 2010 and 2011. In Fall 2010 at Chaska, the lowest mowing height resulted in the greatest percent living turfgrass cover for all seven cultivars/selections (Fig. 2). However, in Fall 2011 at Chaska, the intermediate mowing height at $5.7 \mathrm{~cm}$ resulted in the greatest living turfgrass cover for MNHD, 'Spartan II', and Reliant IV hard fescues, whereas SR 3150 had the most living turfgrass cover at 8.3 and $5.7 \mathrm{~cm}$.

\section{Discussion}

Survey data suggests that most Minnesota homeowners with lawns do not use a standard year-to-year management regime (Carpenter and Meyer, 1999; Yue et al., 2012). Thus, a useful low-input turfgrass should maintain good cover and quality over several years while outcompeting weeds under a range of different mowing heights and fertility levels. The two species that are often used on lawns in the NCR, kentucky bluegrass and perennial ryegrass, performed as expected. At both locations, the mean turfgrass quality of MSP 3769 never reached an acceptable level $(\geq 5)$, and Arctic Green rarely performed at an acceptable level (Tables 3 and 6). The hard fescue entries generally rated the highest for turf quality, particularly in the 2nd year of the trial. These results are not surprising based on other regional studies (Watkins et al., 2011, 2014). Dernoeden et al. (1998) found that hard fescue monostands and mixtures containing hard fescue, maintained without irrigation or fertilization after seedling emergence, provided acceptable turfgrass quality under two different mowing regimes $(6.5$ and $9.0 \mathrm{~cm})$ over a 3-year period. 
Table 7. Mean percent live turfgrass $\operatorname{cover}^{z}$ and weed $\operatorname{cover}^{z}$ of cultivars and selections at St. Paul, MN, in fall of 2010 and 2011.

\begin{tabular}{|c|c|c|c|c|}
\hline & \multicolumn{2}{|c|}{ Percent live cover } & \multicolumn{2}{|c|}{ Percent weed cover } \\
\hline & 2010 & 2011 & 2010 & 2011 \\
\hline \multicolumn{5}{|l|}{ Mowing height $(\mathrm{cm})$} \\
\hline 3.2 & $87.5 \mathrm{a}^{\mathrm{y}}$ & $74.9 \mathrm{a}$ & $10.1 \mathrm{a}$ & $20.6 \mathrm{a}$ \\
\hline 5.7 & $86.4 \mathrm{a}$ & $70.9 \mathrm{a}$ & $11.5 \mathrm{a}$ & $23.6 \mathrm{a}$ \\
\hline 8.3 & $83.6 \mathrm{~b}$ & $70.4 \mathrm{a}$ & $13.7 \mathrm{~b}$ & $24.5 \mathrm{a}$ \\
\hline \multicolumn{5}{|c|}{ Fertilizer treatment $(\mathrm{kg} \mathrm{N} / \mathrm{ha})$} \\
\hline 0 & $84.4 \mathrm{a}$ & $70.8 \mathrm{a}$ & $12.2 \mathrm{a}$ & $23.6 \mathrm{a}$ \\
\hline 49 & $86.4 \mathrm{a}$ & $72.4 \mathrm{a}$ & $11.5 \mathrm{a}$ & $22.6 \mathrm{a}$ \\
\hline 98 & $86.7 \mathrm{a}$ & $73.0 \mathrm{a}$ & $11.6 \mathrm{a}$ & $22.6 \mathrm{a}$ \\
\hline \multicolumn{5}{|c|}{ Cultivar/selection (species) } \\
\hline Arctic Green (PR) & $98.4 \mathrm{ab}$ & $85.7 \mathrm{~b}-\mathrm{d}$ & $0.3 \mathrm{ab}$ & $10.8 \mathrm{~cd}$ \\
\hline MSP $3769(\mathrm{~KB})$ & $94.4 \mathrm{bc}$ & $69.4 \mathrm{f}$ & $3.3 \mathrm{a}-\mathrm{d}$ & $27.1 \mathrm{f}$ \\
\hline MNHD (HF) & $94.7 \mathrm{a}-\mathrm{c}$ & $89.6 \mathrm{a}-\mathrm{c}$ & $5.3 \mathrm{~cd}$ & $10.1 \mathrm{~b}-\mathrm{d}$ \\
\hline SR 3150 (HF) & $94.6 \mathrm{a}-\mathrm{c}$ & $90.0 \mathrm{a}-\mathrm{c}$ & $4.8 \mathrm{a}-\mathrm{d}$ & $9.5 \mathrm{bc}$ \\
\hline Spartan II (HF) & $94.0 \mathrm{bc}$ & $85.6 \mathrm{~cd}$ & $5.4 \mathrm{~cd}$ & $13.9 \mathrm{c}-\mathrm{e}$ \\
\hline Reliant IV (HF) & $94.7 \mathrm{a}-\mathrm{c}$ & $89.6 \mathrm{a}-\mathrm{c}$ & $4.8 \mathrm{~b}-\mathrm{d}$ & $10.0 \mathrm{~b}-\mathrm{d}$ \\
\hline BarKing $(\mathrm{CO})$ & $97.5 \mathrm{ab}$ & $88.6 \mathrm{a}-\mathrm{c}$ & $0.1 \mathrm{ab}$ & $2.0 \mathrm{a}$ \\
\hline Glory $(\mathrm{CO})$ & $98.4 \mathrm{ab}$ & $92.5 \mathrm{ab}$ & $0.0 \mathrm{a}$ & $1.9 \mathrm{a}$ \\
\hline Alister (CO) & $97.7 \mathrm{ab}$ & $93.1 \mathrm{a}$ & $0.0 \mathrm{ab}$ & $0.2 \mathrm{a}$ \\
\hline SR $7150(\mathrm{CO})$ & $96.2 \mathrm{a}-\mathrm{c}$ & $90.1 \mathrm{a}-\mathrm{c}$ & $0.0 \mathrm{a}$ & $0.2 \mathrm{a}$ \\
\hline Barkoel (PJ) & $92.3 \mathrm{c}$ & $81.0 \mathrm{de}$ & $7.4 \mathrm{~d}$ & $18.6 \mathrm{e}$ \\
\hline MN pop. (PJ) & $38.9 \mathrm{~d}$ & $11.2 \mathrm{~g}$ & $56.2 \mathrm{ef}$ & $85.2 \mathrm{~g}$ \\
\hline CO pop. (PJ) & $31.8 \mathrm{e}$ & $10.1 \mathrm{~g}$ & $59.1 \mathrm{f}$ & $86.1 \mathrm{~g}$ \\
\hline ND pop. (PJ) & $42.3 \mathrm{~d}$ & $14.9 \mathrm{~g}$ & $52.1 \mathrm{ef}$ & $80.6 \mathrm{~g}$ \\
\hline Barcampsia (TH) & $97.9 \mathrm{ab}$ & 75.9 ef & $0.7 \mathrm{a}-\mathrm{c}$ & $13.1 \mathrm{c}-\mathrm{e}$ \\
\hline DCM (TH) & $99.1 \mathrm{a}$ & $84.6 \mathrm{~cd}$ & $0.1 \mathrm{ab}$ & $4.2 \mathrm{ab}$ \\
\hline DCS $(\mathrm{TH})$ & $95.8 \mathrm{a}-\mathrm{c}$ & $73.1 \mathrm{f}$ & $0.8 \mathrm{a}-\mathrm{c}$ & $16.2 \mathrm{de}$ \\
\hline
\end{tabular}

$\mathrm{CO}=$ colonial bentgrass; $\mathrm{CO}$ pop. $=$ population originating from germplasm collections made in Colorado; $\mathrm{HF}=$ hard fescue; $\mathrm{KB}=$ kentucky bluegrass; $\mathrm{MN}$ pop. = population originating from germplasm collections made in Minnesota; ND pop. = population originating from germplasm collections made in North Dakota; $\mathrm{PJ}=$ prairie junegrass; $\mathrm{PR}=$ perennial ryegrass; $\mathrm{TH}=$ tufted hairgrass; $\mathrm{TQ}=$ turfgrass quality.

${ }^{2}$ Percent live turfgrass cover and weed cover were calculated using the grid intersect method. Measurements were taken in the fall of 2010 and 2011 at St. Paul.

${ }^{y}$ Means within the same column and treatment with the same letter are not significantly different $(\alpha=0.05)$ according to Fisher's protected least significant difference.

Together, these results suggest that the range of management conditions under which hard fescue can perform well makes it well suited for widespread use in Minnesota and similar northern locations.

In this study, colonial bentgrass had very good turfgrass quality in spring and fall, superior resistance to weed invasion, and good living turf cover throughout the majority of the study. We observed some brown patch (Rhizoctonia solani Kühn) disease on the colonial bentgrass cultivars (data not shown), which impacted turf quality in Summer 2010. In addition, Microdochium patch [Microdochium nivale (Fr.) Samuels \& I.C. Hallett] and Typhula blight (Typhula incarnate Fr. Na; Typhyla ishikariensis Imai) damage on the colonial bentgrasses was quite severe during the Winter of 2010-11, especially at St. Paul (data not shown). Susceptibility to these common turfgrass diseases may reduce the use of this species in lower input environments. Thatch development is also a potential limitation to using colonial bentgrass in lower-input environments, causing lower turfgrass quality than some of the other top-performing grasses. Rinehart et al. (2005) evaluated two colonial bentgrass cultivars at both $1.9-$ and $3.8-\mathrm{cm}$ mowing heights at two different nitrogen rates (4.9 or $14.7 \mathrm{~g} \mathrm{~N} / \mathrm{m}^{2} /$ year). They found that when mowed at $3.8 \mathrm{~cm}$ in the Pacific Northwest, colonial bentgrass developed an unacceptable amount of thatch at both nitrogen fertility levels. In the current trial, we did not measure thatch directly, but over the course of the study we observed considerable thatch development in the colonial bentgrass entries.

Barkoel prairie junegrass performed well throughout the trial, whereas the native populations of this species did not provide acceptable turf quality at any time. Poor establishment of prairie junegrass, and native grasses in general, has been previously reported (Leinauer et al., 2010; McKernan et al., 2001; Watkins et al., 2011). Poor mowing quality due to leaf shredding is also a current limitation to the use of prairie junegrass as a turfgrass (Clark and Watkins, 2010b). Unlike the native populations, Barkoel provided superior turf quality and functionality, especially when maintained with moderate fertility (49 or $98 \mathrm{~kg} \mathrm{~N} /$ ha/year) and mowed at a height of $3.2 \mathrm{~cm}$. Likewise, Mintenko et al. (2002) evaluated a number of low-input turfgrasses in Canada and found that Barkoel performed well at three different mowing heights $(1.8,3.8$, and 6.2 $\mathrm{cm})$. In our trial, the tufted hairgrass entries had higher turfgrass quality ratings in the spring, which then declined through the summer and fall mainly due to rust (Puccinia spp.) disease and summer stress. These stresses have been reported as deficiencies of this species (Brilman and Watkins, 2003; Watkins and Meyer, 2005; Watkins et al., 2007).
Several other species that have shown promise for use in low-input environments were not considered for inclusion in this study. For instance, sheep fescue was not considered due to the high amount of diversity in germplasm and confusion regarding taxonomic designations (Huff and Palazzo, 1998). In addition, when evaluated in Minnesota, sheep fescue has performed similarly to hard fescue (Watkins et al., 2011, 2014). Redtop was also not included in the current study. Its use has declined significantly since the 1940 s when it was used as a nursery grass (Brilman, 2003). Johnson (2013) compared redtop to a number of low-input grasses in Utah under summer drought conditions and found that it did not do as well as several other species. Redtop outperformed some species in the trial by Diesburg et al. (1997); however, turf quality ratings were below acceptable at most locations regardless of mowing height. The inclusion of redtop in a lowinput turfgrass study was not necessary as colonial bentgrass has shown greater potential in a northern climate such as Minnesota.

All the species included in our study, with the exception of kentucky bluegrass, are bunch-type species, with colonial bentgrass producing some short stolons and rhizomes. This type of growth often leads to decreased recovery from damage, in which case weed invasion is more likely. Weed invasion was reduced in grasses that were able to maintain a dense canopy throughout the trial. Our results concur with others showing that fine fescues can persist under lower-input conditions while competing successfully with weeds. Individual cultivars of hard fescue have been found to be allelopathic against large crabgrass (Digitaria sanguinalis L.), curly cress (Lepidium sativum L.), and lettuce (Lactuca sativa L.) (Bertin et al., 2009). It should be noted that of the three indicator species tested in that trial, only one is a weed in turf systems. Nevertheless, this trait could be playing a role in our observed results.

Higher mowing heights have typically been shown to reduce weed invasion (Busey, 2003). For instance, smooth crabgrass (Digitaria ischaemum Schreb.) has been shown to decrease as mowing height is increased in both fine fescue (Dernoeden et al., 1998) and tall fescue (Dernoeden et al., 1993). Interestingly, our results at Chaska showed that higher mowing heights led to increased weed pressure, especially from birdsfoot trefoil. A similar trend was identified in tall fescue invasion by white clover (Trifoloium repens L.) by Dernoeden et al. (1993) who found that higher mowing heights led to a reduction in smooth crabgrass invasion, but an increase in white clover invasion over a 3-year period. Conversely, Miltner et al. (2005) found that when perennial ryegrass was maintained at $98 \mathrm{~kg} \mathrm{~N} / \mathrm{ha} /$ year, leguminous weed cover generally increased with decreased mowing height, although this association was not detected at higher rates of nitrogen (196 or 
Table 8. Mean percent live turfgrass $\operatorname{cover}^{\mathrm{z}}$ and weed $\operatorname{cover}^{\mathrm{z}}$ of cultivars and selections at Chaska, MN, in fall of 2010 and 2011 .

\begin{tabular}{|c|c|c|c|c|}
\hline & \multicolumn{2}{|c|}{ Percent live cover } & \multicolumn{2}{|c|}{ Percent weed cover } \\
\hline & 2010 & 2011 & 2010 & 2011 \\
\hline \multicolumn{5}{|l|}{ Mowing height $(\mathrm{cm})$} \\
\hline 3.2 & $68.0 \mathrm{a}^{\mathrm{y}}$ & $10.0 \mathrm{a}$ & $29.4 \mathrm{a}$ & $24.9 \mathrm{a}$ \\
\hline 5.7 & $60.4 \mathrm{ab}$ & $12.9 \mathrm{a}$ & $37.5 \mathrm{ab}$ & $43.8 \mathrm{~b}$ \\
\hline 8.3 & $55.6 \mathrm{~b}$ & $15.1 \mathrm{a}$ & $43.1 \mathrm{~b}$ & $45.2 \mathrm{~b}$ \\
\hline \multicolumn{5}{|c|}{ Fertilizer treatment $(\mathrm{kg} \mathrm{N} / \mathrm{ha})$} \\
\hline 0 & $55.5 \mathrm{~b}$ & $11.2 \mathrm{a}$ & $41.6 \mathrm{~b}$ & $39.6 \mathrm{~b}$ \\
\hline 49 & $55.4 \mathrm{~b}$ & $12.2 \mathrm{a}$ & $43.1 \mathrm{~b}$ & $44.0 \mathrm{~b}$ \\
\hline 98 & $73.1 \mathrm{a}$ & $14.7 \mathrm{a}$ & $25.4 \mathrm{a}$ & $30.3 \mathrm{a}$ \\
\hline \multicolumn{5}{|l|}{ Cultivar (species) } \\
\hline Arctic Green (PR) & $61.6 \mathrm{~d}-\mathrm{f}$ & $11.6 \mathrm{~cd}$ & $36.9 \mathrm{~cd}$ & $30.5 \mathrm{~cd}$ \\
\hline MSP 3769 (KB) & $54.5 \mathrm{~g}$ & $8.6 \mathrm{de}$ & $44.5 \mathrm{e}$ & $38.6 \mathrm{e}-\mathrm{g}$ \\
\hline MNHD (HF) & $61.2 \mathrm{e}-\mathrm{g}$ & $40.6 \mathrm{a}$ & $38.7 \mathrm{de}$ & $34.0 \mathrm{c}-\mathrm{f}$ \\
\hline SR 3150 (HF) & $63.4 \mathrm{c}-\mathrm{e}$ & $35.1 \mathrm{a}$ & $36.4 \mathrm{~cd}$ & $39.2 \mathrm{fg}$ \\
\hline Spartan II (HF) & $68.1 \mathrm{c}-\mathrm{d}$ & $27.8 \mathrm{~b}$ & $31.9 \mathrm{~b}-\mathrm{d}$ & $42.1 \mathrm{fg}$ \\
\hline Reliant IV (HF) & $69.7 \mathrm{bc}$ & $38.6 \mathrm{a}$ & $30.2 \mathrm{bc}$ & $34.1 \mathrm{c}-\mathrm{f}$ \\
\hline BarKing $(\mathrm{CO})$ & $79.5 \mathrm{a}$ & $2.4 \mathrm{f}$ & $19.7 \mathrm{a}$ & $26.9 \mathrm{bc}$ \\
\hline Glory $(\mathrm{CO})$ & $83.2 \mathrm{a}$ & $4.0 \mathrm{ef}$ & $16.0 \mathrm{a}$ & $17.0 \mathrm{a}$ \\
\hline Alister (CO) & $81.2 \mathrm{a}$ & $5.0 \mathrm{ef}$ & $17.2 \mathrm{a}$ & $19.1 \mathrm{a}$ \\
\hline SR $7150(\mathrm{CO})$ & $78.8 \mathrm{a}$ & $1.3 \mathrm{f}$ & $18.9 \mathrm{a}$ & $22.4 \mathrm{a}$ \\
\hline Barkoel (PJ) & $70.7 \mathrm{~b}$ & $5.6 \mathrm{ef}$ & $29.0 \mathrm{~b}$ & $36.3 \mathrm{~d}-\mathrm{g}$ \\
\hline MN pop. (PJ) & $38.1 \mathrm{~h}$ & $0.0 \mathrm{f}$ & $57.2 \mathrm{fg}$ & $75.7 \mathrm{~h}$ \\
\hline CO pop. (PJ) & $35.9 \mathrm{~h}$ & $0.0 \mathrm{f}$ & $61.4 \mathrm{~g}$ & $77.5 \mathrm{~h}$ \\
\hline ND pop. (PJ) & $38.6 \mathrm{~h}$ & $0.0 \mathrm{f}$ & $58.8 \mathrm{fg}$ & $72.3 \mathrm{~h}$ \\
\hline Barcampsia (TH) & $56.1 \mathrm{fg}$ & $8.1 \mathrm{de}$ & $38.6 \mathrm{de}$ & $31.1 \mathrm{c}-\mathrm{e}$ \\
\hline $\mathrm{DCM}(\mathrm{TH})$ & $60.8 \mathrm{e}-\mathrm{g}$ & $15.0 \mathrm{c}$ & $35.4 \mathrm{~b}-\mathrm{d}$ & $19.1 \mathrm{a}$ \\
\hline DCS (TH) & $41.0 \mathrm{~h}$ & $11.6 \mathrm{~cd}$ & $52.7 \mathrm{fg}$ & $29.8 \mathrm{~b}-\mathrm{d}$ \\
\hline
\end{tabular}

$\mathrm{CO}=$ colonial bentgrass; $\mathrm{CO}$ pop. $=$ population originating from germplasm collections made in Colorado; $\mathrm{HF}=$ hard fescue; $\mathrm{KB}=$ kentucky bluegrass; $\mathrm{MN}$ pop. = population originating from germplasm collections made in Minnesota; ND pop. = population originating from germplasm collections made in North Dakota; $\mathrm{PJ}=$ prairie junegrass; $\mathrm{PR}=$ perennial ryegrass; $\mathrm{TH}=$ tufted hairgrass; $\mathrm{TQ}=$ turfgrass quality.

${ }^{2}$ Percent live turfgrass cover and weed cover were calculated using the grid intersect method. Measurements were taken in the fall of 2010 and 2011 at St. Paul.

${ }^{\mathrm{y}}$ Means within the same column and treatment with the same letter are not significantly different $(\alpha=0.05)$ according to Fisher's protected least significant difference.

$294 \mathrm{~kg} \mathrm{~N} / \mathrm{ha} /$ year). DeBels et al. (2012) showed that increasing mowing height was more effective at reducing weeds in a number of cool-season turfgrasses, including kentucky bluegrass and chewings fescue, compared with increasing nitrogen fertility rates when returning clippings. The benefit of reducing smooth crabgrass likely outweigh potential invasion from leguminous weeds; still, this may be an interesting topic for further study.

Although other researchers have found that increased nitrogen rate reduces weed abundance in chewings fescue (DeBels et al., 2012; Jagschitz and Ebdon, 1985), kentucky bluegrass (DeBels et al., 2012; Heckman et al., 2000), and perennial ryegrass (DeBels et al., 2012; Miltner et al., 2005), we did not observe the same trend in our trial. This could be due to a number of factors including the use of differing nitrogen rates and cultivars, and particularly differences in the predominant weed species across trials. For example, in the study by DeBels et al. (2012) common dandelion (Taraxacum officinale L.) and grassy weed species were predominant; whereas birdsfoot trefoil and black medic were the most prevalent weed species at Chaska. At locations where leguminous weed species are predominant, turfgrass managers may be able to manage these grass species with very little nitrogen fertilization considering the
Table 9. Significance of mowing height on percent live turfgrass cover within cultivar/selection at Chaska, MN, in Fall 2010 and 2011.

\begin{tabular}{lccc}
\hline Cultivar/selection (species) & df & 2010 & 2011 \\
\hline Arctic Green (PR) & 2 & NS & NS \\
MSP 3769 (KB) & 2 & NS & NS \\
MNHD (HF) & 2 & $*$ & $* * *$ \\
SR 3150 (HF) & 2 & $* *$ & $* * *$ \\
Spartan II (HF) & 2 & $* *$ & $* *$ \\
Reliant IV (HF) & 2 & $* *$ & $* * *$ \\
BarKing (CO) & 2 & NS & NS \\
Glory (CO) & 2 & NS & NS \\
Alister (CO) & 2 & NS & NS \\
SR 7150 (CO) & 2 & NS & NS \\
Barkoel (PJ) & 2 & $* * *$ & NS \\
MN pop. (PJ) & 2 & NS & NS \\
CO pop. (PJ) & 2 & NS & NS \\
ND pop. (PJ) & 2 & $*$ & NS \\
Barcampsia (TH) & 2 & $*$ & NS \\
DCM (TH) & 2 & NS & NS \\
DCS (TH) & 2 & NS & NS \\
\hline CO
\end{tabular}

$\overline{\mathrm{CO}}=$ colonial bentgrass; $\mathrm{CO}$ pop. $=$ population originating from germplasm collections made in Colorado; $\mathrm{HF}=$ hard fescue; $\mathrm{KB}=$ kentucky bluegrass; $\mathrm{MN}$ pop. = population originating from germplasm collections made in Minnesota; ND pop. = population originating from germplasm collections made in North Dakota; PJ = prairie junegrass; $\mathrm{PR}=$ perennial ryegrass; $\mathrm{TH}=$ tufted hairgrass; TQ $=$ turfgrass quality.

$*, * *, * * *$ Significant at $\alpha=0.05,0.01$, and 0.001 , respectively. $\mathrm{NS}=$ nonsignificant.

\section{Literature Cited}

Alderson, J. and W.C. Sharp. 1994. Grass varieties in the United States. Lewis Publishers, Boca Raton, FL.

Bertin, C., A.F. Senesac, F.S. Rossi, A. DiTommaso, and L.A. Weston. 2009. Evaluation of selected fine-leaf fescue cultivars for their turfgrass quality and weed suppressive ability in field settings. HortTechnology 19:660668 .

\section{Conclusions}

These data suggest that hard fescue, colonial bentgrass, and Barkoel prairie junegrass could be used as low-input turfgrasses in Minnesota and can perform adequately at several mowing heights and fertility levels. Our results also demonstrate that the tufted hairgrass entries and native prairie junegrass populations require further genetic improvement before being used broadly in the region. The tufted hairgrass entries did perform well during the spring, so breeders should focus on the development of summer stress tolerance in the species. Native prairie junegrass populations showed no potential as turf; however, the performance of Barkoel demonstrates the potential of this species as a low-input turf. The use of Barkoel is limited across the region in part due to challenges in seed production. Previous research has shown that some of the native populations, while lacking turfgrass quality traits, may be a useful source for the genetic improvement of seed production prairie junegrass (Clark and Watkins, 2010a). This evaluation was done on plots composed of single cultivars or selections. Future research should address the performance of these grasses in multispecies mixtures.
Bonos, S.A. and D.R. Huff. 2013. Cool-season grasses: Biology and breeding, p. 591-660. In: J.C. Stier, B.P. Horgan, and S.A. Bonos (eds.). Turfgrass: Biology, use, and management. American Society of Agronomy, Crop Science Society of America, Soil Science Society of America, Madison, WI.

Brilman, L. 2003. Redtop, highland bentgrass, and Idaho bentgrass, p. 207-223. In: M.D. Casler and R.R. Duncan (eds.). Turfgrass biology, genetics, and breeding. Wiley, New York, NY.

Brilman, L. and E. Watkins. 2003. Hairgrasses, p. 225-231. In: M.D. Casler and R.R. Duncan (eds.). Turfgrass biology, genetics, and breeding. Wiley, New York, NY.

Busey, P. 2003. Cultural management of weeds in turfgrass. Crop Sci. 43:1899-1911.

Carpenter, P.J. and M.H. Meyer. 1999. Edina goes green part III: A survey of consumer lawn care knowledge and practices. HortTechnology 9: 491-494.

Clark, M.D. and E. Watkins. 2010a. Seed production characteristics of prairie junegrass germplasm accessions. Crop Sci. 50:10571065.

Clark, M.D. and E. Watkins. 2010b. Turfgrass characteristics of prairie junegrass germplasm accessions. Crop Sci. 50:2092-2102.

cli-MATE. 2015. St. Paul climatological observatory and national weather service Chaska weather data. Midwestern Regional Climate Center. 11 Dec. $2015<\mathrm{http}: / /$ mrcc.isws.illinois. edu/CLIMATE/>. 
DeBels, B.T., S.E. Griffith, W.C. Kreuser, E.S. Melby, and D.J. Soldat. 2012. Evaluation of mowing height and fertilizer application rate on quality and weed abundance of five home lawn grasses. Weed Technol. 26:826-831.

Dernoeden, P.H., M.J. Carroll, and J.M. Krouse. 1993. Weed management and tall fescue quality as influenced by mowing, nitrogen, and herbicides. Crop Sci. 33:1055-1061.

Dernoeden, P.H., M.A. Fidanza, and J.M. Krouse. 1998. Low maintenance performance of five Festuca species in monostands and mixtures. Crop Sci. 38:434-439.

Diesburg, K.L., N.E. Christians, R. Moore, B. Branham, T.K. Danneberger, Z. Reicher, T.B. Voigt, D.D. Minner, and R. Newman. 1997. Species for low-input sustainable turf in the U.S. Upper Midwest. Agron. J. 89:690694.

Heckman, J.R., H. Liu, W. Hill, M. DeMilia, and W.L. Anastasia. 2000. Kentucky bluegrass responses to mowing practice and nitrogen fertility management. J. Sustain. Agr. 15:2533.

Huff, D.R. and A.J. Palazzo. 1998. Fine fescue species determination by laser flow cytometry. Crop Sci. 38:445-450.

Jagschitz, J.A. and J.S. Ebdon. 1985. Influence of mowing, fertilizer and herbicide on crabgrass infestation in red fescue turf. Intl. Turfgrass Soc. Res. J. 5:699-704.

Johnson, P.G.J. 2013. Evaluation of Chinese and Kyrgyzstan grass germplasm collections for maintenance of green cover under limited irrigation in western North America. Intl. Turfgrass Soc. Res. J. 12:305-317.

Leinauer, B., M. Serena, and D. Singh. 2010. Seed coating and seeding rate effects on turfgrass germination and establishment. HortTechnology 20:179-185.

McKernan, D.K., J.B. Ross, and D.K. Tompkins. 2001. Evaluation of grasses grown under low maintenance conditions. Intl. Turfgrass Soc. Res. J. 9:25-32.

Miltner, E.D., G.K. Stahnke, and G.J. Rinehart. 2005. Mowing height, nitrogen rate, and organic and synthetic fertilizer effects on perennial ryegrass quality and pest occurrence. Intl. Turfgrass Soc. Res. J. 10:982-988.

Mintenko, A.S., S.R. Smith, and D.J. Cattani. 2002 Turfgrass evaluation of native grasses for the northern Great Plains region. Crop Sci. 42: 2018-2024.

Rinehart, G.J., E.D. Miltner, and G.K. Stahnke 2005. Nitrogen rate and mowing height effects on turfgrass quality and thatch development of colonial, velvet, and dryland bentgrasses. Intl. Turfgrass Soc. Res. J. 10:422-427.

Watkins, E., S.A. Bonos, M.D. Clark, and W.A Meyer. 2009. Ploidy determination of tufted hairgrass germplasm using flow cytometry. Intl. Turfgrass Soc. Res. J. 11:599-605.

Watkins, E., L. Brilman, and D. Kopec. 2013. Development of native grasses for turf, $\mathrm{p}$. 661-681. In: J.C. Stier, B.P. Horgan, and S.A. Bonos (eds). Turfgrass: Biology, use, and management. American Society of Agronomy, Crop Science Society of America, Soil Science Society of America, Madison, WI.

Watkins, E. and M.D. Clark. 2009. Genetic improvement of prairie junegrass. USGA Turfgrass and Environ. Res. Online 8:1-8.

Watkins, E., S. Fei, D. Gardner, J. Stier, S. Bughrara, D. Li, C. Bigelow, L. Schleicher, B. Horgan, and K. Diesburg. 2011. Low-input turfgrass species for the north central United States. Appl. Turfgrass Sci. doi: 10.1094/ ATS-2011-0126-02-RS.

Watkins, E., D.S. Gardner, J.C. Stier, D.J. Soldat, R.A. St. John, N.E. Christians, A.D. Hathaway, K.L. Diesburg, S.R. Poppe, and R.E. Gaussoin. 2014. Cultivar performance of low-input turfgrass species for the north central United States. Appl. Turfgrass Sci. doi: 10.2134/ats-2013-0101-rs.

Watkins, E., B. Huang, and W.A. Meyer. 2007. Tufted hairgrass responses to heat and drought stress. J. Amer. Soc. Hort. Sci. 132:289-293.

Watkins, E. and W.A. Meyer. 2005. Evaluation of tufted hairgrass germplasm as lowmaintenance turf. Intl. Turfgrass Soc. Res. J. 10:666-673.

Yue, C., K. Hugie, and E. Watkins. 2012. Are consumers willing to pay more for low-input turfgrasses on residential lawns? Evidence from choice experiments. J. Agr. Appl. Econ. 44:549-560. 